\title{
MANFAAT PENGGUNAAN MEDIA SOSIAL TERHADAP PENINGKATAN PENJUALAN TAS PADA PENGRAJIN TAS DI CIAMPEA
}

Oleh:

\author{
Leny Muniroh $^{\text {a }}$, Hurriyaturrohman ${ }^{\mathrm{b}}$ dan Asti Marlina ${ }^{\mathrm{c}}$ \\ ${ }^{\text {a }}$ Fakultas Ekonomi Univesitas Ibn Khaldun Bogor, Indonesia \\ ${ }^{\mathrm{b}}$ Fakultas Ekonomi Univesitas Ibn Khaldun Bogor, Indonesia \\ ${ }^{\mathrm{c}}$ Fakultas Ekonomi Univesitas Ibn Khaldun Bogor, Indonesia
}

\begin{abstract}
ABSTRAK
Globalisasi dan pasar bebas serta Masyarakat Ekonomi ASEAN atau MEA yang merupakan sistem perdagangan bebas atau free trade antara negara-negara anggota ASEAN menjadi tantangan bagi Usaha Kecil dan Menengah (UKM) untuk terus bertahan.Perubahan dan perkembangan di dunia IPTEK ini, tidak bisa dipungkiri sedikit banyak pasti mempengaruhi segala aspek kehidupan kita saat sekarang ini. Dengan kata lain, IPTEK adalah suatu hal yang wajib dan krusial bagi kehidupan manusia saat ini, dan untuk masa depan yang akan datang. Di era modernisasi, pemasaran juga tidak dapat hanya dilakukan secara konvensional dengan melakukan pemasaran di lapangan tetapi kita juga harus mulai menggunakan pemasaran modern dengan berbasis online.Banyaknya manfaat yang dapat dirasakan oleh UKM dengan penggunaan media sosial merupakan salah satu faktor pendorong yang kuat bagi UKM untuk terus memanfaatkan media sosial dalam rangka mengembangkan produk, melakukan komunikasi dengan konsumen, penyalur maupun pemasok, serta mengembangkan jaringan pasar yang lebih luas lagi. Penggunaan media sosial dapat meningkatkan volume penjualan walaupun dalam penelitian ini belum menghasilkan peningkatan penjualan secara signifikan karena waktu yang digunakan untuk internet masih

tergolong sebentar yaitu 1-5 jam perhari. perdagangan bebas atau free

Kata kunci: Media sosial, UKM, trade antara negara-negara penjualan.

\section{PENDAHULUAN}

\subsection{Latar Belakang}

Globalisasi dan pasar bebas

serta Masyarakat Ekonomi ASEAN

atau MEA yang merupakan sistem

anggota ASEAN menjadi

tantangan bagi Usaha Kecil

dan Menengah (UKM) untuk

terus

bertahan.
\end{abstract}


Perkembangan sektor UKM yang

demikian menyiratkan bahwa

terdapat potensi yang besar jika hal ini dapat

dikelola dan dikembangkan dengan baik

tentu akan dapat mewujudkan usaha menengah

yang

tangguh.

Begitu juga dengan para

pengrajin tas di Bojong Rangkas Ciampea

Kabupaten Bogor. Derasnya arus

informasi dan semakin bebasnya

kompetisi telah meningkatkan

kesadaran konsumen dan pelanggan akan

banyaknya pilihan produk

barang dan jasa yang dapat

dipilih.Dunia bisnis semakin

maju.Pemasaran merupakan kunci

kesuksesan suatu usaha baik bidang jasa

maupun produk.

Di era modernisasi,

pemasaran juga tidak dapat hanya

dilakukan secara konvensional dengan

melakukan pemasaran di lapangan tetapi

kita juga harus mulai menggunakan

pemasaran modern dengan berbasis online.

Perubahan dan

perkembangan di dunia IPTEK ini,

tidak bisa dipungkiri sedikit

banyak pasti

mempengaruhi segala aspek

kehidupan kita saat sekarang ini. Dengan kata lain, IPTEK adalah suatu hal yang wajib dan krusial bagi kehidupan manusia saat ini, dan untuk masa depan yang akan datang. Ada seorang ahli mengatakan bahwa, ilmu pengetahuan merupakan fondasi bagi teknologi sedangkan teknologi adalah tulang punggung pembangunan.

Salah satu potensi yang dapat

dimanfaatkan adalah potensi teknologi informasi. Teknologi informasi

menawarkan banyak manfaat bagi

pengrajin tas untuk meningkatkan

produktivitas dan pemasarannya.

Selain itu juga meningkatkan

kesempatan para pengrajin tas untuk bekerjasama dengan pengusaha lainnya. Salah satu teknologi informasi yang 
sedang berkembang pesat dan sangat berpotensi untuk mendorong kinerja para pengrajin tas adalah media sosial.

\section{Penggunaan Media Sosial}

juga berpengaruh terhadap pengrajin tas

untuk meningkatkan penjualan, apabila

tidak mengikuti trendmaka mereka akan

terancam kalah bersaing dan gulung tikar.

Untuk itu, para pengrajin perlu melihat

berbagai potensi alternatif media

untuk dimanfaatkan menjadi

media

pemasaran. Dan juga membenahi diri serta membangun hubungan jangka panjang dengan konsumen dan

pelanggan.

Hingga saat ini, masih jarang

publikasi tentang penggunaan media

sosial pada para pengrajin tas dan manfaat

penggunaan media sosial bagi para

pengrajin tas di Indonesia, khususnya

untuk pengrajin Tas diCiampea.

Mengingat pentingnya informasi

tentang bagaimana penggunaan

media sosial bagi pengrajin tas dan manfaatnya, maka perlu dilakukan

suatu penelitian

observasional. Penelitian ini bertujuan untuk mengetahui gambaran penggunaan media sosial pada pengrajin tas di Ciampea dan manfaatnya bagi perkembangan mereka.

\subsection{Rumusan masalah}

Berdasarkan latar belakang masalah di atas dapat dirumuskan masalah sebagai berikut :

Apakah ada manfaatnya media sosial terhadap peningkatan penjualan tas pada pengrajin tas di Bojong Rangkas

Kecamatan Ciampea Bogor?

\subsection{Tujuan Penelitian}

Untuk mengetahui manfaat media sosial terhadap peningkatan penjualan tas pada pengrajin tas di Bojong

Rangkas Kecamatan Ciampea Bogor. 


\section{4 waktu dan lokasi penelitian}

Penelitian dilakukan pada bulan Agustus 2017 dan lokasi penelitian di Desa Bojong Rangkas Kecamatan

Ciampea Bogor.

\section{II.LANDASAN TEORI}

\subsection{Pengertian Pemasaran Online}

Pemasaran online adalah pemasaran secara online yang dilakukan melalui sistem computer online interaktif yang menghubungkan pelanggan dengan penjual secara

elektronik

\subsection{Pengertian Media sosial}

Menurut Kaplan dan Haenlein (2010), media sosial adalah sekelompok aplikasi berbasiskan internet yang dibangun berdasarkan kerangka pikiran ideologi dan teknologi dari Web 2.0, dan memungkinkan terbentuknya kreasi pertukaran isi informasi dari pengguna internet. Web 2.0 adalah dasar terbentuknya sosial media (Carlsson, 2010).

Media sosial adalah sebuah media online, dengan para penggunanya bisa dengan mudah berpartisipasi, berbagi, dan menciptakan isi meliputi blog,

jejaring sosial, wiki, forum dan dunia virtual. Blog, jejaring sosial dan wiki merupakan bentuk media sosial yang paling umum digunakan oleh masyarakat di seluruh dunia. Pendapat lain mengatakan bahwa media sosial adalah media online yang mendukung interaksi sosial dan media sosial menggunakan teknologi berbasis web yang mengubah komunikasi menjadi dialog interaktif.

Jejaring sosial merupakan situs dimana setiap orang bisa membuat web page pribadi, kemudian terhubung dengan teman-teman untuk berbagi informasi dan berkomunikasi. Jejaring sosial terbesar antara lain 
Facebook, Myspace, dan Twitter. Jika media tradisional menggunakan media cetak dan media broadcast, maka media sosial menggunakan internet. Media sosial mengajak siapa saja yang tertarik untuk berpartisipasi dengan memberi kontribusi dan feedback secara terbuka, memberi komentar, serta membagi informasi dalam waktu yang cepat dan tak terbatas.

\subsection{Ciri-ciri media sosial}

Media sosial mempunyai ciri-ciri, yaitu sebagai berikut :

a. Pesan yang di sampaikan tidak hanya untuk satu orang saja namun bisa keberbagai banyak orang contohnya pesan melalui SMS ataupun internet

b. Pesan yang di sampaikan bebas, tanpa harus melalui suatu Gatekeeper

c. Pesan yang di sampaikan cenderung lebih cepat di banding media lainnya d. Penerima pesan yang menentukan waktu interaksi

\subsection{Peran dan Fungsi Media Sosial}

Media sosial merupakan alat promosi bisnis yang efektif karena dapat diakses oleh siapa saja, sehingga jaringan promosi bisa lebih luas. Media sosial menjadi bagian yang sangat diperlukan oleh pemasaran bagi banyak perusahaan dan

merupakan salah satu cara terbaik untuk menjangkau pelanggan dan klien. Media sosial seperti blog, facebook, twitter, dan youtube memiliki sejumlah manfaat bagi

perusahaan dan lebih cepat dari media konvensional seperti media cetak dan iklan TV, brosur dan selebaran.

\section{METODE PENELITIAN}

\subsection{Desain Penelitian dan Subyek}

\section{Penelitian}

Penelitian ini merupakan penelitian deskriptif 
observasional pada Usaha Kecil

Menengah (UKM) di wilayah kabupaten

Bogor yaitu pengrajin tas di Bojong Rangkas

Ciampea Bogor. Menggunakan

metode triangulasi, yang

menggabungkan metode wawancara

terstruktur, wawancara mendalam dan

observasi terhadap UKM dan media sosial yang digunakan.

Subyek dalam penelitian ini adalah

pemilik atau pengelola UKM yang

dipilih secara purposive sampling.

Subyek dipilih sesuai

dengan kriteria:

1) merupakan pemilik atau pengrajin

tas

2) pernah menggunakan media sosial

dalam komunikasi perusahaan,

bersedia menjadi subyek

penelitian. Total subyek yang direkrut

dalam penelitian sebanyak 16 pengguna

media social dari 25

pengrajin yang diteliti.

\subsection{Metode Pengumpulan Data}

Penelitian ini menggunakan data primer yang diperoleh berdasarkan wawancara terstruktur dan wawancara mendalam kepada pemilik/pengrajin. Data yang diperoleh meliputi data karakteristik umum, data penggunaan sosial media dalam perusahaan, termasuk tujuan, manfaat dan hambatan yang dihadapi. Data dilengkapi dengan hasil observasi peneliti terhadap pengrajin dan media sosial yang digunakan.

\subsection{Analisis Data}

Data yang diperoleh dianalisis menggunakan statistik deskriptif dan analisis kualitatif serta ditampilkan dalam bentuk tabel.

\section{IV .HASIL DAN PEMBAHASAN}

\subsection{Karakteristik UKM}

Subyek dalam penelitian ini adalah pemilik atau pengelola UKM 
dengan jenis usaha barang tas dan dompet,

sebagian besar UKM yang

diteliti telah berdiri antara 0-5 tahun dan 5-

10 tahun dan 10 tahun ke atas

a. Berdasarkan Jenis Kelamin

b. Berdasarkan Pendidikan
UKM / Pengrajin yang menjadi

obyek penelitian sebanyak 25

orang $(100 \%)$ berjenis kelamin

laki-laki.

Tabel 1

Pendidikan Pengrajin (UKM) Tas Bojong Rangkas Ciampea Bogor

Dari 25 Pengrajin yang diteliti

\begin{tabular}{|c|c|c|}
\hline Jenjang Pendidikan & Jumlah & $\begin{array}{c}\text { Persentase } \\
\%\end{array}$ \\
\hline SD & 8 & 32 \\
\hline SMP & 6 & 24 \\
\hline SMA & 9 & 36 \\
\hline Sarjana & 2 & 8 \\
\hline Jumlah & 25 & 100 \\
\hline
\end{tabular}

Data hasil olahan

Pada tabel 1, Pendidikan pengrajin dari jumlah 25 orang yang diteliti, pendidikan dengan persentase paling tinggi yaitu jenjang pendidikan SMA sebanyak 9 orang (36\%), disusul kemudian SD dengan jumlah 8 orang (32\%), kemudian SMP 6 orang (24\%), dan terakhir sarjana 2 orang $(8 \%)$.

c. Berdasarkan Umur

Tabel 2

Umur Pengrajin (UKM) Tas Bojong Rangkas Ciampea Bogor

Dari 25 Pengrajin yang diteliti

\begin{tabular}{|c|c|c|}
\hline $\begin{array}{c}\text { Umur } \\
\text { (Tahun) }\end{array}$ & Jumlah & $\begin{array}{c}\text { Persentase } \\
\%\end{array}$ \\
\hline $20-30$ & 6 & 24 \\
\hline $31-50$ & 17 & 68 \\
\hline Diatas 50 & 2 & 8 \\
\hline Jumlah & 25 & 100 \\
\hline
\end{tabular}


Data hasil olahan

Terlihat pada tabel 2 bahwa rata- rata umur pengrajin mayoritas ada dikisaran 3150 tahun yaitu sebanyak 17 orang (68\%). Menunjukkan bahwa usia mereka ada pada usia menjelang tua. Sementara pada usia 20-30 tahun hanya 6 orang (24\%), dimana pada usia tersebut menunjukkan usia dewasa yang mempunya semangat kerja yang tinggi yang mampu menghadapi berbagai tantangan termasuk resiko .

d. Berdasarkan Bidang Usaha

Tabel 3

Bidang Usaha Kerajinan di Bojong Rangkas Ciampea Bogor

\begin{tabular}{|c|c|c|}
\hline Bidang Kerajinan & Jumlah & $\begin{array}{c}\text { Persentase } \\
\%\end{array}$ \\
\hline Tas & 16 & 64 \\
\hline Dompet & 7 & 28 \\
\hline Lainnya ( mis. Agenda ) & 2 & 8 \\
\hline Jumlah & 25 & 100 \\
\hline
\end{tabular}

Data hasil olahan

Pada tabel 3, Tas merupakan produk primadona yang diproduksi pengrajin di Bojong Rangkas Ciampea, hal ini terlihat jumlah pengrajin yang bergerak dibidang tas mencapai $64 \%$, atau sebanyak 16 orang dari 25 UKM yang diteliti.

e. Lama Usaha

Tabel 4

\begin{tabular}{|c|c|c|}
\hline Lama Usaha Tahun & Jumlah & Persentase \\
\hline $0-5$ & 3 & 12 \\
\hline $5-10$ & 15 & 60 \\
\hline Diatas 10 & 7 & 28 \\
\hline Jumlah & 25 & 100 \\
\hline
\end{tabular}

Data hasil olahan 
Pada tabel 4, rata-rata 15 UKM sudah memulai usahanya 5-10 tahun atau sebanyak 60\%, lama usaha 0-5 tahun berjumlah 3 UKM, yang artinya UKM tersebut masuk dalam kategori baru memulai atau merintis usahanya.

\subsection{Penggunaan Media Sosial}

Seluruh UKM yang menjadi subyek penelitian ini berjumlah 25 orang, hasil dari penelitian terdapat 16 orang yang telah menggunakan media sosial sebagai media informasi dan komunikasi dalam menjalankan usahanya. Sebagian besar dari pengguna media social baru menggunakan media social selama 1-2 tahun yaitu sejumlah 9 UKM ( $56,25 \%)$, sementara yang lainnya sebanyak 4 UKM sudah menggunakan 3-4 tahun (25 \%), dan sebanyak 3 UKM yang sudah menggunakan media social lebih dari 4 tahun.

Tabel 5

Pengguna Media Sosial oleh UKM

\begin{tabular}{|l|c|c|}
\hline \multicolumn{1}{|c|}{ Variabel } & Jumlah & Persentase\% \\
\hline $\begin{array}{l}\text { Apakah setelah menggunakan media social terdapat } \\
\text { peningkatan penjualan? a. Iya } \\
\text { b. Tidak }\end{array}$ & & \\
& & \\
& 5 & 68,75 \\
\hline Jika iya, berapa persen peningkatan tersebut? & & 31,25 \\
a. 5-10 & 14 & 87,5 \\
b. 11-20 & 1 & 6,25 \\
c. Diatas 20 & 1 & 6,25 \\
\hline Barang apa yang dijual secara online? d. & 11 & $*$ \\
$\quad$ Tas & 7 & 68,75 \\
e. Dompet & 2 & 12,75 \\
f. Lainnya & & $*$ \\
\hline Media social yang digunakan untuk menjual secara online ? & 13 & 81,25 \\
a. Facebook & 5 & $31,2512,5$ \\
b. Instagram & 2 & 31,25 \\
c. Line & 5 & \\
d. BBM & & \\
\hline
\end{tabular}




\begin{tabular}{|c|c|c|}
\hline $\begin{array}{l}\text { Media elektronik apa yang digunakan untuk menjual secara } \\
\text { online? } \\
\text { a. PC } \\
\text { b. Smartphone } \\
\text { c. Tablet }\end{array}$ & $\begin{array}{c}1 \\
15 \\
0\end{array}$ & $\begin{array}{c}6,25 \\
93,75 \\
0\end{array}$ \\
\hline $\begin{array}{l}\text { Berapa jam yang anda habiskan untuk online sehari? } \\
\begin{array}{l}\text { a. } \\
\text { b. } 6-5 \\
\text { c. lebih dari } 10\end{array}\end{array}$ & $\begin{array}{c}16 \\
0 \\
0\end{array}$ & $\begin{array}{c}100 \\
0 \\
0\end{array}$ \\
\hline $\begin{array}{l}\text { Media social apa yang anda miliki ? } \\
\text { a. Facebook } \\
\text { b. Instagram } \\
\text { c. Line } \\
\text { d. BBM }\end{array}$ & $\begin{array}{l}13 \\
5 \\
2 \\
5\end{array}$ & $\begin{array}{l}* \\
81,25 \\
31,2512,5 \\
31,25\end{array}$ \\
\hline
\end{tabular}

Data hasil olahan

Hampir seluruh UKM

menggunakan Facebook,

pengguna media sosial pada penelitian

kemudian diikuti,

ini sebanyak 11 UKM, mengalami

Instagram, BBM, dan Line.

peningkatan pendapatan setelah

Dengan jumlah $\quad 13,5,5$,dan $\quad 2$,

melakukan penjualan produknya

dengan

melalui media sosial.

persentasi $81,25 \%, 31,25 \%$, dan

Peningkatan pendapatan dari

$12,5 \%$.

penjualan melalui media sosial ini

tergolong masih sangat kecil yaitu 510

\% sebanyak 14 UKM, dan 1 UKM

mengalami peningkatan

pendapatannya di 11-20\%, dan 1 UKM

yang mengalami peningkatan

4.3 ManfaatPenggunaan Media

\section{Sosial pada UKM}

Penggunaan media sosial pada

UKM memberikan manfaat

diantaranya sebagai sarana kontak

penjualannya diatas $20 \%$.

personil dengan konsumen,

Media sosial yang digunakan

untuk menjual produk secara online

adalah mayoritas

bermanfaat sebagai sarana promosi,

mendata kebutuhan konsumen,

menyampaikan respon kepada

konsumen dan sebagai dasar 
pengambilan keputusan bisnis / usaha. Di

samping itu media social juga bermanfaat

sebagai forum diskusi online, memantau

pelanggan secara online, survey pelanggan,

mendata kebutuhan penyalur, mendata

kebutuhan pemasok, serta untuk

menampilkan galeri produk.

Banyaknya manfaat yang

dapat dirasakan oleh UKM dengan

penggunaan media social merupakan salah

satu faktor pendorong yang kuat bagi

UKM untuk terus memanfaatkan

media social dalam rangka

mengembangkan produk, melakukan

komunikasi dengan konsumen, penyalur

maupun pemasok, serta mengembangkan

jaringan pasar yang

lebih luas lagi.

Media sosial merupakan

salah satu media yang mempermudah

komunikasi interaktif

antara

pengusaha dengan siapapun, termasuk

konsumen, penyalur, pemasok, dan berbagai pihak yang

berkepentingan, kapanpun

dimanapun berada.Media sosial

sangat membantu sebagai media

penghubung informasi dan

komunikasi dari produsen ke

konsumen dimanapun mereka

berada berapapun jarak mereka.

\section{PENUTUP}

\subsection{Kesimpulan}

UKM dalam penelitian ini sebagian besar telah menggunakan media sosial dalam komunikasi usahanya. Media sosial yang paling banyak digunakan adalah Facebook, kemudian diikuti, Instagram, BBM, dan Line. Dengan jumlah 13,5,5,dan 2, dengan persentasi $81,25 \%, 31,25$ $\%$, dan $12,5 \%$.

Banyaknya manfaat

yang dapat dirasakan oleh

UKM dengan penggunaan media sosial merupakan salah satu factor 
pendorong yang kuat bagi UKM untuk

terus memanfaatkan

media sosial dalam rangka

mengembangkan produk, melakukan

komunikasi dengan konsumen,

penyalur maupun pemasok, serta

mengembangkan jaringan pasar yang

lebih luas lagi. Penggunaan media

sosial dapat meningkatkan volume

penjualan walaupun dalam penelitian

ini belum menghasilkan peningkatan

penjualan secara signifikan karena

waktu yang digunakan untuk internet

masih tergolong sebentar yaitu 1- 5 jam

perhari.

\subsection{Saran}

Untuk meningkatkan pangsa pasar dan

volume penjualan, UKM perlu

memanfaatkan media sosial secara optimal dan dilakukan

update

informasi setiap hari secara

konsisten. Perlu dilakukan penelitian

lanjut untuk mengetahui peranan

ataupun kontribusi penggunaan media social terhadap peningkatan

penjualan. Karena pada

penelitian ini UKM yang

menggunakan media sosial masih

tergolong baru dan

peningkatan hasil penjualannya

pun belum memuaskan.

\section{DAFTAR PUSTAKA}

Ghobakhloo, M., Sabouri, M.S., Hong, T.S., Zulkifli, N., 2011.

Information Technology

Adoption in Small and

Mediumsized Enterprises;

An appraisal of two

literature. Interdisciplinary

Journal of Research in

Business, 1 (7), pp. 53-80.

Saravanakumar, M., Lakshmi, T.S., 2012.Social Media Marketing.

Life Science Journal, 9 (4), pp. 4444-4451.

Neti, S., 2011.Social Media and Its Role in Marketing. International Journal of Enterprise Computing and Bussiness System, 1 (2), pp. 1-16.

Kuzma, J., Bell, V., Logue, C., 2014.A study of the use of social media marketing in the football industry.Journal of Emerging Computing and Information Sciences, 5 (10), pp. 728-738. 
Edomwan, S., Prakasan, S.K., Kouame,

D., Watson, J., Seymour, T., 2011.

The History of Social Media and Its Impact on

Business. The Journal of Applied

Management and

Entrepreneurship, 16 (3), pp. 113.

Carter, J., 2014. Social Media

Strategies in Small Business.

Manchester: Manchester

Metropolitan University.

http://id.wikipedia.org/wiki/Media_sosi

al

http://jayaputrasbloq.blogspot.com/201

1/02/definisi-atau-pengertianistilahsocial.html 